\title{
The Application Countermeasures of New Media Interaction Technology in the Teaching of Kindergarten Play and Teaching Aids Making*
}

\author{
Deqiang Liu \\ Linyi University \\ Linyi, China
}

\begin{abstract}
The new media is used as an auxiliary teaching aid in the teaching of kindergarten play and teaching aids making. With its rich teaching resources and controllable repeatable interactive features, the new media has improved the efficiency of teachers' teaching and students' learning. This article mainly expounds the advantages of the new media interaction technology in applying to the teaching of kindergarten play and teaching aids making and the attentions of schools, teachers, and students when they are using the new media interaction technology, and proposes new ideas for the application of new media interaction technology in the teaching of kindergarten play and teaching aids making.
\end{abstract}

Keywords-new media; interactive technology; classroom teaching

\section{INTRODUCTION}

With the rapid development of new media technologies, "new media" has become an indispensable tool in people's life and learning. For example, teachers and students of five-year preschool education major use the new media in teaching and learning of kindergarten play and teaching aids making. On the one hand, the new media can be used as a teaching aid. With its rich teaching resources and controllable repeatable interactive features, the new media can provide students with demonstrations of kindergarten play and teaching aids making skills. This will not only stimulate students' initiative in selflearning, but also make the content of the teaching more vivid and intuitive. It will help students master the skills of kindergarten play and teaching aids making, and make the teaching of kindergarten play and teaching aids making become short-term, efficient and easy to learn. On the other hand, the application of the new media interaction technology in the teaching of kindergarten play and teaching aids making helps students to understand science and art better and promotes the development of students' sense of innovation, innovative thinking, and innovative ability. Therefore, the application of the new media interaction technology in the teaching of kindergarten play and teaching aids making is of great significance to improving the quality of education and training innovative and entrepreneurial talents.

*This article is the result of the special art project "Application of New Media Interaction Technology in Kindergarten Play and Teaching Aid Making Teaching".

\section{AdVANTAgeS OF APPLYING NEW MEdia INTERACTION TECHNOLOGY IN THE MAKING OF KINDERGARTEN PLAY AND TEACHING AIDS}

\section{A. From the Perspective of Students}

1) The new media interaction technology can mobilize students' various senses and increase their interests in learning: The application of the new media interactive technology breaks the traditional teaching mode of "teacher + textbook + blackboard", solves the problems that dynamic presentation is difficult, takes long time, and has cumbersome operations in the teaching process, and improves students' learning efficiency. In the actual teaching process, the new media interaction technology can make many concepts expressed only by language and difficult-to-understand logical relationships become intuitive, vivid, and interesting. It can attract the attention of students, bring new stimuli to students, awaken students' interest in learning, mental emotions and brain thinking, and enable students to learn more effectively. At the same time, effective class interaction can stimulate students' interests of learning kindergarten play and teaching aids making and desire to explore knowledge, and help to develop students' independent thinking, selfexploring capabilities, so that they can produce practical kindergarten play and teaching aids.

2) New media interaction technology can broaden students' learning scope and communication channels: The new media interaction technology is highly interactive. It can shorten the time and cycle of knowledge dissemination, make the expression of knowledge more vivid, learning ways more convenient, and the scope of learning more extensive. In class teaching, students can use computers or mobile phones to browse many kindergarten teaching and play aids and children's use of various teaching aids in the classroom. This will enable students to understand the role of various kindergarten play and teaching aids in practical teaching. Teachers can also arrange students to collect materials about the learning topics through the network before class. Students will learn more knowledge in the process of gathering information. Students can also use the new media interaction 
technology to communicate with students in different regions and with different cultural backgrounds after learning. Students can even communicate and interact with preschool education experts online. It is also possible to hold student work exchange meetings among individuals, schools or kindergartens.

\section{B. From the Perspective of Teachers}

The use of new media interaction technology in kindergarten play and teaching aids making teaching can produce better class effects. Effective interactive teaching can arouse teachers' enthusiasm and help improve teachers' teaching organization abilities and level of applying new media interaction technology to kindergarten play and teaching aids making teaching. At the same time, after the combination of new media interaction technology and classroom teaching, the interaction of teaching becomes stronger, teachers ' teaching ideas and teaching purposes become clearer, the teaching content is more easily understood and mastered by students, teaching effects are better, and the time and space constraints for traditional teaching mode are broken, the teaching contents and teaching methods have been enriched. Strong sound, light, image and other visual and audio effects make students change from passive to active, promote the classroom teaching mode of kindergarten play and teaching aids making to transform from unidirectional to interactive, enhance the feedback of teaching, improve the effectiveness of teaching, ensure that students transform from the "object" to the "subject" in the classroom, help students to change from "passive learning" to active learning, and cultivate students' abilities of discovering problems, solving problems, cooperative inquiry and self-expression, awareness of innovation, spirit of independence and will of perseverance.

\section{New Media Interaction Technology Can Provide Clear Demonstration}

When teachers are instructing students to learn the skills of making kindergarten play and teaching aids, in addition to making language explanations, they can use the new media interaction technology to put practical steps into new media courseware and upload it to QQ learning groups or WeChat groups so that students can watch the teachers' steps at any time. This will not only shorten the time, but also be more intuitive, which is conducive to students' mastering the skills of kindergarten play and teaching aids making.

\section{New Media Interaction Technology Can Provide a Learning and Communication Platform for Art Teachers}

The new media interaction technology not only provides rich teaching resources for the art teachers, but also provides them with a platform for learning and communication, providing conditions for teachers to realize lifelong learning. At present, there are many QQ groups and WeChat public platforms about the teaching of kindergarten play and teaching aids making on the Internet. The contents involve teaching theory, teaching plan design, and teaching methods of kindergarten play and teaching aids making. In practical teaching, many art teachers obtain relevant materials through various new media, and at the same time they can review and exchange ideas with each other, which in turn improves their artistic literacy.

\section{THE REQUIREMENTS OF APPLYING NEW MEDIA} INTERACTIVE TECHNOLOGY TO KINDERGARTEN PLAY AND TEACHING AIDS MAKING

\section{A. Requirements for the Offices of Academic Affairs in Colleges and Universities}

- Provide training courses to improve teachers' ability to use new media interactive technology in teaching.

According to the conclusion of this study, the new media interaction technology plays an important role in improving the learning effect of students, that is, the more the use of new media interaction technology in teaching, the better the students' learning effect. Therefore, in order to improve students' learning effect, the academic affairs offices in higher education institutions should vigorously strengthen the training of teachers in the use of new media interaction technology. The training of new media technology for teachers not only requires them to master the basic skills of using new media, but also requires them to be able to make common teaching software. What is more important is that teachers should master the basic theories and application methods of new media interaction technology.

- Utilize new media interaction technology to enrich the teaching resources for art teachers.

With the wide application of $3 \mathrm{G}$ and $4 \mathrm{G}$ technologies, mobile terminals represented by smart phones have gradually become the main tools for teachers to obtain and disseminate information. The teaching departments in colleges and universities should make full use of the advantages of new media, proactively occupy new media territories represented by mobile phone networks and instant messaging software, enrich the teaching resources on the Internet, guide teachers to correctly use new media, and carry out the teaching work in colleges and universities in interactive, experiential, guided and osmotic ways. Research and explore the use of WeChat, QQ groups and other methods to carry out teaching work; use mobile phone network to push mobile newspapers, learning tasks, micro-videos, micro-classes, discussion communities, etc.; research and explore the use of social networking sites, campus network groups and other new ways to create campus culture, making the campus network community a good platform for teachers and students to carry out learning and communication activities.

- Form good teaching management system for new media interactive technology and scientific research mechanism for the application of new media interactive technology, make the school's research of new media interactive technology and teaching become scientific and regular. 


\section{B. Requirements for Fine Arts Teachers in Colleges and Universities}

1) Using new media to achieve "mobile learning": Mobile learning refers to any form of learning that can occur anywhere, anytime with the help of smart phones or portable electronic devices. Teachers can use new media such as WeChat, Weibo, and QQ to update their knowledge structures anytime, anywhere, and use mobile phones, tablet computers, etc. to conduct fragmented learning. This approach has much pertinence and flexibility. Most of the education news and teaching suggestions that teachers want to browse can be found on the new media platforms. This learning method is not limited by time, can make teachers acquire a great deal of knowledge in a short time, and is the way that many teachers are willing to use.

2) Use new media to create a teacher discussion platform: In the traditional teaching mode, teachers generally conduct joint learning at school-organized teaching and research conferences, express their opinions on issues raised by other teachers and reflect on their own teaching activities. The use of new media interaction technology can break this traditional model. Teachers no longer need to sit face to face to discuss issues that arise during the teaching processes. They only need to use the Internet and social software to discuss teaching issues in WeChat discussion groups or group videos. This has given much freedom to teaching and research activities in space, broken the time and space constraints for teachers' research activities and achieved satisfactory results.

3) Using new media to create personalized classes: With the development of information technology, teachers can receive virtual skill training through network platforms on the Internet. The development of network platforms is similar to that of games, and the new media interaction technology can also be combined with games, using functions of voice, video, etc. to create a platform for teachers to improve teaching skills and promote the professional development. This bold idea has already been partially realized in countries such as the United States and Australia. Teachers enter the virtual space provided by the platform. The platform will provide teachers with electronic files of students. Teachers will know the characteristics of each student by reading the students' electronic files. The platform also provides two teaching modes for teachers: collective teaching and individualized teaching. In this gamified virtual space, teachers are required to do tasks that are not easier than those in real life. They must first quickly master the conditions of students in a short period of time. Then they should choose the right teaching mode according to the students' conditions and the nature of the subjects. They should also well deal with various emergencies happened in the classes, carefully observe the students' subtle reactions and reflect on their own teaching. Although this is only a game and not a real teaching activity, it has trained teachers' teaching ability to a certain extent. It reflects the teachers' teaching styles and teaching experience, and teachers can recognize what they lack. This platform integrates skill training into games. Because it enables teachers to independently choose the teaching mode, it also to some extent satisfies the professional development of teachers in the new media environment.

\section{Requirements for Preschool Education Students}

1) Fully understand the advantages and disadvantages of new media: Various values, lifestyles and ethos on the Internet will have a strong impact on the value standards of students. The junk information of online media will, to some extent, be misleading to the values of contemporary college students. Under the stimulation of various bad information, the mainstream values of college students may become blurred. Under the influence of material consumption, sensory stimulation and hedonism, some undergraduates will lose the judgment ability and break away from the real life, forming the values that are characterized by personal hedonism and material consumerism. Therefore, college students should consciously improve their media literacy and improve their ability to identify various information. When facing the complicated information from the new media, college students must have the ability to analyze it rationally, choose useful information according to their needs in life and learning, and get away from bad information.

2) Strengthen self-management and avoid indulging in mobile phones: First of all, as adults who have reached the age of 18 , college students should gradually learn to rationally allocate time and scientifically set goals after leaving their parents. They should establish their own networks of interpersonal relationships in school and learn how to communicate with others. Second, college students must learn to use the advantages of new media effectively to serve their own development, such as the use of mobile phone alarm clock and memo functions to reasonably arrange time; organizing literature and sports salons through the campus network, mobile phones and other platforms; taking proper physical exercise and taking part in some cultural and recreational activities. Finally, it is recommended that college students install anti-addictions plug-ins, correct or prevent bad habits such as smoking, drinking, and indulging in video games, and train logical thinking and attention through reading paper books.

3) Be good at using new media to improve learning efficiency and professional quality: College students should use the new media to acquire the knowledge and information that are conducive to their own learning and growth, and to construct reasonable knowledge structures. College students should train their own ability of independent thinking and solving problems independently under the premise of rationally using new media to get information, should not rely too much on the complex information provided by the new media and should focus on the learning in real life. Under the premise of using the Internet to search for relevant knowledge, students should actively participate in the discussions and exchanges in real-life classes. Students should combine the 
views on the Internet with the discussions in classes to form their own ways of thinking and cultivate their own habits of independently finishing the homework and self-evaluation.

\section{CONCLUSION}

In short, the new media interactive technology can provide teachers and students with more approaches to teaching and learning in the pre-class preparation, classroom presentation, after-school online space resource sharing, material collection, and play and teaching aids creation of the kindergarten play and teaching aids making curriculum, making the classroom teaching of the curriculum more free and lively. At the same time, the new media interactive technology has improved students' interest in learning and learning efficiency. Students can understand the cutting-edge issues of the development of art, their artistic vision can be broadened, and their artistic expressions can be enriched.

\section{REFERENCES}

[1] Liu Ting. Intelligent Construction Design-A New Idea of Playing and Teaching Aid Design [D]. Nanjing Normal University, 2013. 刘婷. 智 能建构设计一玩教具设计新理念 [D]. 南京师范大学, 2013 .

[2] Yuan Weiwei, Li Xunxiang. New ideas of the application of digital interactive media in the teaching of art courses [J]. Asia-Pacific Education, 2015(24):101. 苑维维,李勋祥. 数字交互媒体在美术课程教 学应用中的新思路[J].亚太教育,2015(24):101.

[3] Gao Jiangze. Application and Research of Multimedia Teaching Means in the Art and Design Courses in Secondary Vocational Education [D]. Inner Mongolia Normal University, 2010. 高江泽. 多媒体教学手段在 中职美术与设计课程中的运用与研究[D].内蒙古师范大学, 2010

[4] Zhou Guangying. Application Strategies of New Media in Art Classes in Middle Schools[J]. Art Education Research, 2016(18):pp.119-120. 周 广英. 浅谈新媒体在中学美术课堂中的应用策略 [J]. 美术教育研 究,2016(18):119-120.

[5] Li Dandan. Research on the perfect combination of digital new media and fine arts teaching in higher vocational colleges[D]. Northeast Normal University, 2010. 李丹丹. 数字新媒体与高职高专美术教学完 善结合探究[D].东北师范大学, 2010 .

[6] Liu Dahai. Research on Strategies of Using Digital Technology to Innovate the Art Teaching in the Internet+ Environment[J]. Electronic production,2016(12):pp.59-60. 刘大海.互联网+环境下运用数字技术 创新美术教学策略研究[J].电子制作,2016(12):59-60.

[7] Wen Ran. Research on the interactive teaching of art courses in middle schools based on new media[D]. Henan Normal University, 2014. 温然. 基于新媒体的中学美术交互性教学研究[D].河南师范大学,2014. 